\title{
PENINGKATAN HASIL BELAJAR SISWA MELALUI MODEL NUMBER HEAD TOGETHER BERBANTUAN MEDIA POHON PINTAR TEMA 7 KELAS IV SDN MARGOREJO O1 PATI
}

\author{
Khofi Anan ${ }^{1, *)}$, Mohammad Kanzunnudin ${ }^{2)} \&$ Khamdun $^{3)}$ \\ 1), 2), 3) Universitas Muria Kudus, Kota Kudus, Indonesia \\ E-mail: khofianan2@gmail.com
}

\begin{tabular}{|c|c|}
\hline ARTICLE INFO & ABSTRAK \\
\hline $\begin{array}{l}\text { Article history } \\
\text { Received: August 18, } 2020 \\
\text { Revised: August 20, } 2020 \\
\text { Accepted: August 23, } 2020 \\
\text { Kata Kunci: } \\
\text { NHT, pohon pintar, hasil } \\
\text { belajar }\end{array}$ & $\begin{array}{l}\text { Penelitian ini bertujuan untuk mendeskripsikan peningkatan keterampilan } \\
\text { guru, peningkatan hasil belajar siswa ranah pengetahuan dan keterampilan } \\
\text { dengan menggunakan model number head together berbantuan media pohon } \\
\text { pintar pada tema } 7 \text { kelas IV SDN Margorejo 01 Pati. Materi di dalam tema } 7 \\
\text { kelas IV muatan IPA dan Bahasa Indonesia yang dikaji pada penelitian ini } \\
\text { adalah macam-macam gaya dan teks nonfiksi. Penelitian tindakan kelas ini } \\
\text { akan dilaksanakan pada kelas IV SDN Margorejo OI Pati dengan subjek } \\
\text { penelitian } 22 \text { siswa. Hasil penelitian keterampilan mengajar guru dari siklus } \\
\text { I sebesar } 72 \% \text { dan pada siklus II mengalamai peningkatan sebesar } 83,5 \% \text {. } \\
\text { Hasil belajar ranah pengetahuan muatan Bahasa Indonesia dari siklus I } \\
\text { sebesar } 63,63 \% \text { dan pada siklus II meningkat menjadi } 77,27 \% \text {. Sedangkan } \\
\text { pada muatan IPA siklus I sebesar } 72,72 \% \text { dan pada siklus II mengalami } \\
\text { peningkatan sebesar } 86,36 \% \text {. }\end{array}$ \\
\hline
\end{tabular}

\section{A. PENDAhuluan}

Kurikulum adalah suatu program pendidikan yang disediakan untuk membelajarkan siswa. Dengan program itu para siswa melalukan berbagai kegiatan siswa, sehingga terjadi perubahan dan perkembangan tingkah laku siswa, sesuai dengan tujuan pendidikan dan pembelajaran. Dengan kata lain, sekolah menyediakan lingkungan bagi siswa yang memberikan kesempatan belajar.

Belajar merupakan aktivitas siswa yang disengaja dan dilakukan oleh individu agar terjadi perubahan kemampuan diri, dengan belajar anak yang tadinya tidak mampu melakukan sesuatu, menjadi mampu melakukan sesuatu, atau anak yang tadinya tidak terampil menjadi terampil. Gagne (1984), belajar adalah suatu proses dalam suatu organisme berubah perilakunya sebagai akibat pengalaman. Proses mental dan emosional atau proses berpikir dan merasakan.

Seorang dikatakan belajar apabila pikiran dan perasaannya aktif, akan tetapi dirasakan oleh bersangkutan sendiri. Pembelajaran suatu upaya yang dilakukan oleh guru atau pendidik untuk membelajarkan siswa yang belajar, tugas dibebankan kepada guru, karena guru 
merupakan tenaga professional yang untuk dipersiapkan agar sekolah semakin berkembang. SDN Margorejo 01 Pati salah satu sebagai lembaga pendidikan formal.

Berdasarkan obervasi yang peneliti lakukan pada 30 Oktober 2019 menemukan beberapa permasalahan dikelas IV yaitu masih banyaknya siswa yang kurang aktif, jenuh, dan bosan dalam proses pembelajaran. dikarenakan pada pembelajaran yang masih bersifat konvensional, seperti ceramah, pembelajaran merupakan suatu metode pembelajaran yang hanya menerangkan materi pelajaran secara lisan tanpa memperhatikan ada tidaknya respon dari pendengar. Belum maksimalnya pembelajaran berdampak pada rendahnya hasil belajar siswa kelas IV SDN Margorejo 01 Pati.

Berdasarkan data Ulangan Harian diketahui bahwa dari 22 siswa, pada muatan Bahasa Indonesia hanya 10 siswa yang tuntas mencacapi KKM, sementara 12 siswa lainnya belum tuntas KKM. Artinya, sebanyak 54,54\% yang belum tuntas mencapai KKM, dan hanya 45,45\% yang berhasil mencapai KKM. Selanjutnya pada muatan IPA hanya 9 siswa yang tuntas KKM, dan 13 siswa tidak tuntas mencapai KKM. Artinya hanya 40,90\% muatan IPA yang mencapai ketuntasan.

Permasalahan rendahnya hasil belajar dan kurang aktifnya siswa pada proses pembelajaran dapat diatasi dengan model, media, pendekatan dan metode pembelajaran yang bervariasi dan inovasi. Pendekatan yang dipilih dan diterapkan haruslah berpusat pada dua arah, yaitu siswa dan guru, sehingga siswa dapat menjadi aktif dan tanggap pada saat proses pembelajaran berlangsung. Salah satu model pembelajaran yang cocok diterapkan untuk siswa menjadi aktif dan tanggap yakni pembelajaran kooperatif (Cooperative learning) tipe Number Head Together.

Model pembelajaran Number Head Together pada dasarnya merupakan varian dari diskusi kelompok. Teknis pelaksanaannya hampir sama dengan diskusi kelompok. Merupakan pembelajaran kooperatif yang dirancang untuk mempengaruhi pola interaksi siswa dan sebagai alternative terhadap struktur kelas tradisional. Pertama kali dikembangkan oleh Spenser Kagen (1993) untuk melibatkan lebih banyak siswa dalam menelaah materi yang tercakup dalam suatu pelajaran dan mengecek pemahaman mereka terhadap isi pelajaran tersebut.

Kelebihan model pembelajaran Number Head Together menurut Krismanto (2003:63) yaitu: 1) melatih siswa untuk dapat bekerjasama dan menghargai pendapat orang lain, 2) melatih siswa untuk bisa menjadi tutor sebaya, 3) memupuk rasa kebersamaan, 4) membuat siswa menjadi terbiasa dengan perbedaan. Anitah (2012:5) mengatakan bahwa media pembelajaran adalah bahan atau alat yang dapat menciptakan kondisi yang memungkinkan 
Annan, dkk. (2020). Peningkatan Hasil Belajar...

pembelajaran untuk menerima pengetahuan, keterampilan dan sikap. Penerapan model pembelajaran yang baik menjadi bermakna jika digabungkan dengan penggunaan media pembelajaran yang tepat, sehingga membantu siswa memahami materi secara mendalam. Disini peneliti menggunakan model Number Head Together dan media Pohon Pintar.

\section{B. METODE PENELITIAN}

Metode penelitian yang digunakan yakni metode penelitian tindakan kelas. Penelitian dilaksanakan sebanyak dua siklus, dimana setiap siklusnya terdiri atas perencanaan, tindakan, pengamatan, dan refleksi. Penelitian ini dilaksanakan di SDN Margorejo 01 Pati Kecamatan Margorejo Kabupaten Pati. Subjek penelitian yakni siswa kelas IV SDN Margorejo 01 Pati tahun ajaran 2019/2020. Jumlah siswa yang terdapat pada kelas IV yakni sejumlah 22 siswa yang terdiri dari 8 laki-laki dan 14 perempuan.

Prosedur penelitian tindakan yang dilakukan pada awalnya suatu pendirian eksploratori diadopsi, pemahaman masalah dikembangkan, dan rencana dibuat untuk beberapa bentuk strategi intervensi. Selama dan sekitar waktu intervensi dilakukan, pengamatan dilakukan dalam berbagai bentuk. Strategi intervensi baru dilakukan, dan proses siklus diulangi, dilanjutkan sampai pemahaman yang cukup atau menerapkan solusi yang mampu untuk terhadap suatu masalah yang diperoleh.

Langkah - langkah dalam model Number Head Together yakni siswa dibagi dalam kelompok, setiap siswa dalam setiap kelompok mendapat nomor. Guru memberikan tugas dan masing-masing kelompok mengerjakannya. Kelompok mendiskusikan jawaban yang benar dan memeriksakan tiap anggota kelompok dapat mengerjakannnya atau mengetahui jawabannya dengan baik. Guru memanggil salah satu nomor siswa dan nomor dipanggil keluar dari kelompoknya dan melaporkan atau menjelaskan hasil kerjasama mereka. Tanggapan dengan teman lain, kemudian guru menunjuk nomor lain, kemudian melakukan kesimpulan.

Teknik pengumpulan data meliputi teknik wawancara, observasi, tes, dan dokumentasi. Validitas data menggunakan teknik validitas isi dengan expert judgment dan analisis yang digunakan yaitu analisis data kualitatif dan kuantitatif. Indikator keberhasilan yang diharapkan untuk keterampilan guru mencapai persentase $\geq 70 \%$. Selanjutnya untuk hasil belajar siswa ranah pengetahuan mencapai KKM yakni 75 dengan persentase $\geq 70 \%$.

\section{HASIL DAN PEMBAHASAN}

Penelitian tindakan kelas dilakukan dengan persetujuan guru kelas IV, dimana didapatkan kesepakatan bahwa siklus I dilaksanakan pada 17-18 Februari 2020, dimana 
pertemuan 1 dilaksanakan pada 17 Februari 2020 dan pertemuan 2 dilaksanakan pada 18 Februari 2020. Siklus II dilaksanakan pada 26 dan 27 Februari 2020, dimana pertemuan 1 dilaksanakan 26 Februari dan pertemuan 2 dilaksanakan 27 Februari 2020.

Berdasarkan analisis yang telah dilakukan pada setiap siklusnya, hasil data yang diperoleh sebagai berikut.

\section{Keterampilan Mengajar Guru}

Data hasil observasi keterampilan guru dalam penerapan model Number Head Together berbantuan media Pohon Pintar kelas IV SDN Margorejo 01 Pati disajikan dalam Tabel 1 berikut.

Tabel 1. Peningkatan Keterampilan Mengajar Guru Siklus I-II

\begin{tabular}{cc}
\hline Pelaksanaan & Data \\
\hline Siklus I & $72 \%$ \\
Siklus II & $83,5 \%$ \\
\hline
\end{tabular}

Tabel 1. Menunjukkan bahwa dalam pembelajaran menggunakan model Number Head Together berbantuan media Pohon Pintar kelas IV SDN Margorejo 01 Pati terjadi peningkatan di setiap siklusnya. Rata-rata siklus I sebesar 72\% dan meningkat sebesar 11,5\% menjadi $83,5 \%$ pada siklus II.

Nasution (2008:115) mengungkapkan bahwa seorang pengajar harus menguasai kemahiran dalam berbagai gaya mengajari ilmu dan mesti sanggup menjalankan berbagai peranannya. Selanjutnya Imron (1995) menetapkan depalan keterampilan guru mengajar, yakni 1) keterampilan guru dalam membuka pelajaran, 2) keterampilan bertanya, 3) keterampilan memberikan penguatan, 4) keterampilan memberikan variasi, 5) keterampilan menjelaskan, 6) keterampilan membimbing diskusi kelompok kecil, 7) keterampilan mengelola kelas, 8) keterampilan mengajar perseorangan dan keterampilan menutup pelajaran.

Temuan yang ada menunjukkan bahwa pemberian materi yang sesuai dengan kehidupan nyata membuat siswa lebih baik dalam menyerap pembelajaran, daripada pemberian materi atau contoh yang siswa belum pernah melihatnya. Kemudian penggunaan media pembelajaran sangat menunjang terjadinya kelas yang aktif dan menyenangkan bagi siswa. Dengan menggunakan media pembelajaran yang sesuai materi, maka guru dimudahkan dalam proses penyampaian informasi sekaligus siswa dimudahkan dalam menangkap informasi. Oleh karena itu penggunaan media pembelajaran yang tepat mampu mencapai tujuan pembelajaran yang ingin dicapai. 


\section{Hasil Belajar Siswa Ranah Pengetahuan}

Rekapitulasi ketuntasan hasil belajar siswa ranah pengetahuan dengan penerapan model Number Head Together berbantuan media Pohon Pintar kelas IV SDN Margorejo 01 Pati disajikan dalam Tabel 2.

Tabel 2. Peningkatan Hasil Belajar Ranah Pengetahuan Siklus I-II

\begin{tabular}{cc}
\hline Pelaksanaan & Data \\
\hline Siklus I & $72,72 \%$ \\
Siklus II & $86,36 \%$ \\
\hline
\end{tabular}

Terdapat enam indikator hasil belajar ranah pengetahuan menurut Murtono (2017) yakni pengetahuan atau ingatan $(\mathrm{C} 1)$, pemahaman $(\mathrm{C} 2)$, aplikasi atau penerapan (C3), analisis (C4), evaluasi (C5), dan mencipta (C6). Tabel 2 menunjukkan perkembangan hasil belajar siswa ranah pengetahuan mengalami peningkatan pada setiap siklusnya. Ketuntasan klasikal siswa pada siklus I sebesar $72,72 \%$ lalu meningkat sebesar $14,72 \%$ pada siklus II menjadi $86,36 \%$.

Berdasarkan hasil penelitian diketahui bahwa masih ada kekurangan pada model Number Head Together dan media Pohon Pintar dikarenakan beberapa siswa ada yang bercanda sesame temannya dan membuat kelas gaduh, untuk mengatas permasalahan tersebut, guru mendekati siswa tersebut, kemudian memberikan pengarahan dan menegurnya. Motivasi belajar yang siswa tunjukkan sangat luar biasa dengan digunakannya media Pohon Pintar sebagai media pembelajaran. Motivasi pembelajaran sendiri dibutuhkan untuk mendorong individu dalam melakukan sesuatu kegiatan untuk mencapai tujuan tertentu.

\section{SIMPULAN}

Berdasarkan penelitian tindakan kelas yang telah dilaksanakan di kelas IV SDN Margorejo 01 Pati dapat disimpulkan bahwa penerapan model Number Head Together berbantuan media Pohon Pintar dapat meningkatkan keterampilan mengajar guru dan peningkatan hasil belajar siswa. Keterampilan mengajar guru menunjukkan peningkatan yang mana ada pada siklus I sebesar $72 \%$ dengan kategori baik. Kemudian pada siklus II memperoleh sebesar 83,5\% dengan kriteria sangat baik. Sehingga keterampilan mengajar guru telah mencapai indikator keberhasilan dengan kriteria minimal 70\%. Hasi belajar siswa ranah pengetahuan mengalami peningkatan, pada muatan Bahasa Indonesia dari siklus I sebesar $72,72 \%$ dan siklus II menjadi 86,36\%.

\section{DAFTAR PUSTAKA}


Annan, dkk. (2020). Peningkatan Hasil Belajar...

Arikunto, Suharsimi (2013). Prosedur Penelitian Suatu Pendekatan Praktik. Jakarta: Rineka Cipta

Arikunto, Suharsini. (2014). Penelitian Tindakan Kelas. Jakarta: PT. Bumi Aksara

Astrawan, I Gede Budi. (2014). "Penerapan Model Kooperatif Tipe NHT dalam Meningkatkan Hasil Belajar Siswa Pada Mata Pelajaran IPA di Kelas V SDN 3 Tonggolobibi”. Jurnal Kreatif Tadulako. 3 (4).

Dahar, Ratna. (2006). Teori-teori belajar dan pembelajaran. Jakarta: Erlangga.

Emzir. (2011). Metodologi Penelitian Pendidikan Kuantitatif dan Kualitatif. Jakarta: PT Raja Grafindo Persada

Huda, Miftahul. (2012). Cooperative Learning, Metode, Teknik, Struktur, dan Model Terapan. Yogyakarta: Pustaka Pelajar

Kanzunnudin, Mohammad. (2011). Bahasa Indonesia Untuk Perguruan Tinggi. Rembang: Yayasan Adhigama.

Lestari K.E dan Yudhanegara, M.R. (2015). Penelitian Pendidikan Matematika. Bandung: PT Refika Aditama.

Luedi. (2017). "Efektivitas Model Pembelajaran Number Head Together (NHT) Terhadap Peningkatan Hasil Belajar Siswa dalam Pembelajaran PKN (Penelitian Tindakan Kelas Pada Siswa Kelas IV SDN Randuagung 05”. Jurnal PTK dan Pendidikan. 3 (1) $9-15$.

Musfah, Jejen. (2011). Peningkatan Kompetensi Guru Melalui Pelatihan dan Sumber Belajar Teori dan Praktik. Jakarta: Prenada Media Group

Ratna Indah Cahyaningsih, dan Gamaliel Septian Airlanda. "Peningkatan Proses dan Hasil Belajar Muatan IPA Melalui Model Pembelajaran Numbered Head Together (NHT) Siswa Kelas 4 SD”. Jurnal Pendidikan. 3 (1) 361-370.

Samatowa. Usman. 2016. Pembelajaran IPA di Sekolah Dasar. Jakarta Barat: Permata Puri Media

Sanjaya, Wina. (2009). Penelitian Tindakan Kelas. Jakarta: Kencana Prenadamedia Group.

Sarumpaet, Toha. (2010). Pedoman Penelitian Anak. Jakarta: Yayasan Pustaka Obor Indonesia.

Shoimin, Aris. (2014). 68 Model Pembelajaran Inovatif dalam kurikulum 2013. Yogyakarta: Ar-Ruzz Media.

Somadayo, Samsu. (2013). Penelitian Tindakan Kelas. Yogyakarta: Graha Ilmu 
Annan, dkk. (2020). Peningkatan Hasil Belajar...

Sudjana, Nana. (2014). Penilaian Hasil Proses Belajar Mengajar. Bandung: PT Remaja Rosdakarya.

Sugiyono. (2016). Metode Penelitian Pendidikan Pendekatan Kuantitatif, Kualitatif dan R\&D. Bandung: Alfabeta

Sukiman. (2012). Pengembangan Media Pembelajaran. Yogyakarta: PT Pustaka Insan Madani.

Triwiyanto, Teguh. (2015). Manajemen Kurikulum dan Pembelajaran. Jakarta: Sinar Grafika Offset.

Ummul Khair. (2018). "Pembelajaran Bahasa Indonesia dan Sastra di SD dan MI”. Jurnal Pendidikan Dasar. 2 (1).

Zukira, Abduh H. Harum, dan Jamaludin. (2014). "Meningkatkan Hasil Belajar Siswa Kelas III Sekolah Dasar Alkhairaat Towera Melalui Model Pembelajaran Kooperatif Tipe Number Head Together (NHT) Pada Mata Pelajaran PKn”. Jurnal Kreatif Tadulako Online. 3 (4).

Wahyulestari, Mas Roro diah. (2018). "Keterampilan Dasar Mengajar di Sekolah Dasar". Prosiding Seminar Nasional Era Revolusi. 199-210

Nurlaili. (2018). “Analisis Keterampilan Dasar Mengajar Guru Dalam Perspektif Guru Pamong Pada Mahasiswa Prodi PGMI Fakultas Ilmu Tarbiyah dan Keguruan UIN Raden Fatah Palembang”. 4 (1). 